April 2009

\title{
A Report from the Field: The Declaration on the Rights of Indigenous Peoples-Implementation and Implications
}

Lori Garcia-Alix

Robert K. Hitchcock

Follow this and additional works at: https://digitalcommons.usf.edu/gsp

\section{Recommended Citation}

Garcia-Alix, Lori and Hitchcock, Robert K. (2009) "A Report from the Field: The Declaration on the Rights of Indigenous Peoples-Implementation and Implications," Genocide Studies and Prevention: An International Journal: Vol. 4: Iss. 1: Article 7.

Available at: https://digitalcommons.usf.edu/gsp/vol4/iss1/7

This Articles is brought to you for free and open access by the Open Access Journals at Digital Commons @ University of South Florida. It has been accepted for inclusion in Genocide Studies and Prevention: An International Journal by an authorized editor of Digital Commons @ University of South Florida. For more information, please contact digitalcommons@usf.edu. 


\title{
A Report from the Field: The Declaration on the Rights of Indigenous Peoples-Implementation and Implications
}

\author{
Lola García-Alix \\ International Work Group for Indigenous Affairs
}

\author{
Robert K. Hitchcock \\ Department of Anthropology, Michigan State University
}

\begin{abstract}
Over nearly two-and-a-half decades, indigenous peoples and their supporters expended enormous energy on developing a declaration on the rights of indigenous peoples that both protects and promotes their individual and collective rights. The debates surrounding the declaration focused on issues ranging from selfdetermination to the rights of indigenous peoples to practice their cultures and to participate in decision making. The declaration establishes the requirement for fair and adequate compensation for violations of rights and directly addresses the issues of ethnocide and genocide. The United Nations General Assembly passed the Declaration on the Rights of Indigenous Peoples on 13 September 2007, with 143 votes in favor, four votes against, and eleven abstentions. Notably, the votes against were cast by Australia, Canada, New Zealand, and the United States. Implementation of the Declaration on the Rights of Indigenous Peoples will be a complex process, especially given that many indigenous communities today are located in places where states, private companies, and individuals are competing for resources, sometimes with deadly results.
\end{abstract}

Keywords: indigenous peoples, United Nations, genocide, Commission on Human Rights

\section{Introduction}

The colonization of what came to be known as the Americas, Africa, Asia, the Pacific, and the Arctic by various European nations from the fifteenth to the nineteenth centuries witnessed the expansion of contacts between indigenous peoples and nonindigenous governments and agencies. Indigenous peoples in these areas were subjected to policies ranging from genocide to paternalism and benign neglect. Most indigenous groups chose to resist actively what they saw as an onslaught. ${ }^{1}$

Of the world's contemporary peoples, those groups defined by themselves or others as indigenous tend to be overrepresented among those lacking basic human rights, living below the poverty line, and working under exploitative or unjust conditions. The indicators of indigenous peoples' deprivation are stark: they tend to have the lowest standards of health and nutrition; the highest rates of unemployment, illiteracy, and mortality; the shortest life spans; the lowest incomes; and the lowest degrees of political participation of the various categories of people in the countries in which they reside. ${ }^{2}$

Lola García-Alix and Robert K. Hitchcock, "A Report from the Field: The Declaration on the Rights of Indigenous Peoples-Implementation and Implications." Genocide Studies and Prevention 4, 1 (April 2009): 99-109. (C) 2009 Genocide Studies and Prevention. doi:10.3138/gsp.4.1.99 
The past several decades have witnessed intensifying efforts, at both the international and the grassroots level, to promote human rights for indigenous peoples. ${ }^{3}$ The indigenous peoples' movements of this period have had a number of impacts, not least on issues relating to genocide and mass killings. As Ronald Niezen points out,

As the regional scope of the movement has moved to new hemispheres, above all to the inclusion of unstable and/or undemocratic states, the form of grievance has also shifted from a more or less uniform pattern of ethnocidal displacement and assimilation to a more frequent inclusion of mass killing, the entanglements of ethnic rivalries, and efforts towards ethnic cleansing. ${ }^{4}$

This shift can be seen, for example, in Bangladesh, Burma (Myanmar), Chad, Colombia, Sudan, and Zimbabwe. ${ }^{5}$

Yet these populations continue to be vulnerable to oppression and exploitation. International conventions and declarations on indigenous and minority rights have often gone unenforced, and, as a result, the rights of members of these groups have been violated with impunity by states, by international agencies, and by private companies and individuals. ${ }^{6}$

\section{International Human-Rights Instruments Involving Indigenous Peoples}

Until relatively recently, only a few international human-rights statements dealt specifically with indigenous peoples. For decades, the only international legal instruments that directly addressed indigenous peoples' rights were Convention No. 107 and Recommendation No. 104 of the International Labor Organization (ILO), which were passed in 1957 and went into effect in 1959. Many indigenous groups felt that they were essentially left out of the debate on the promotion of indigenous rights. ${ }^{7}$

The Civil Rights movements in the United States (1954-1968) and decolonization trends in the developing world in the 1960s provided important lessons for indigenous peoples, and in the 1960s and 1970s indigenous groups began calling for greater recognition of their civil and political rights as well as their social, economic, and cultural rights. Many indigenous groups worked at the local level, attempting to organize their communities, and sought assistance from non-governmental organizations such as churches and humanitarian agencies. Some groups, such as American Indians in the United States, Australian Aboriginals, and various Latin American Indian peoples, formed organizations geared toward promoting their rights and well-being. ${ }^{8}$ Other groups ended up in direct confrontation with the state, as was the case, for example, in Bangladesh, ${ }^{9}$ Brazil, ${ }^{10}$ and Indonesia. ${ }^{11}$

The same period saw the establishment of organizations aimed at supporting indigenous peoples, including the International Work Group for Indigenous Affairs (IWGIA) in 1968, Survival International in 1969, and Cultural Survival in $1972 .^{12}$ These organizations helped bring attention to the plight of indigenous peoples who were being destroyed and dispossessed and whose resources were being exploited by states, private companies, and individuals.

Particularly important to the emergent international indigenous movement were the right of indigenous peoples to self-determination and their right to determine for themselves the kinds of development policies that would affect them.

Indigenous peoples therefore sought to be recognized by the ILO and the United Nations as peoples with particular characteristics and as groups whose physical and cultural survival was threatened.

One of the biggest issues with which many indigenous peoples are concerned is that of autonomy, or, as indigenous leaders put it, "self-determination." 
An examination of the sociopolitical status of indigenous peoples around the world reveals that very few of them are in control of the governments of the countries where they reside and that most of them lack political power even at the regional level. A major reason for this situation is that indigenous peoples were designated by colonial governments as "wards of the state," lacking the legal right to participate in political decision making or to control their own futures. Indigenous peoples around the world have long had to contend with institutionalized discrimination and the lack of recognition of basic civil, political, and socioeconomic rights. ${ }^{13}$

In 1971, the UN Sub-commission on Prevention of Discrimination and Protection of Minorities authorized a study titled "The Problem of Discrimination Against Indigenous Populations." This study, which took years to complete, brought together data on the situations facing indigenous peoples worldwide. ${ }^{14}$ One of the outgrowths of this process in the United Nations was the establishment of the Working Group on Indigenous Populations (WGIP) in May $1982 .{ }^{15}$ The WGIP, which met annually in Geneva, Switzerland, until 2006, was charged with reviewing developments affecting the rights of indigenous peoples and with producing a set of human-rights standards relating to indigenous peoples.

In the $1980 \mathrm{~s}$, a decision was made to revise ILO Convention No. 107 to take diversity among indigenous peoples more directly into account and to produce a document less focused on assimilation than the existing one, the title of which was "For the Protection and Integration of Indigenous and Other Tribal and Semi-tribal Populations in Indigenous Countries." There were disagreements among indigenous groups, including those from the global North and the global South (i.e., developing countries), over the text and emphasis of the new convention, which was eventually passed in $1989 .^{16}$ A major concern of indigenous peoples in the South, such as the Mapuche of Chile, was that they were coping with repressive regimes that, they contended, had extermination as an avowed goal. ${ }^{17}$ Another complaint was that that the convention did not restore to indigenous peoples full property rights over their own lands.

The WGIP, with the participation of indigenous representatives, drew up a draft UN Declaration on the Rights of Indigenous Peoples that was completed in 1993. The following year, the Draft Declaration on the Rights of Indigenous Peoples was adopted by the Sub-Commission on Prevention of Discrimination and Protection of Minorities; it was then forwarded to the Commission on Human Rights (UNCHR), later reorganized by the United Nations as the Human Rights Council. The UNCHR established in 1995 an open-ended inter-sessional working group the sole purpose of which was to elaborate on the draft declaration. A major goal of the UN General Assembly's 1993 proclamation of the International Decade of the World's Indigenous People (1995-2004) was to promote the human rights of indigenous peoples. ${ }^{18}$ One part of this effort was support for efforts to come up with a Declaration on the Rights of Indigenous Peoples.

In 2000, the United Nations established the Permanent Forum on Indigenous Issues (PFII), which held its inaugural session in May 2002. The PFII's aims include strengthening international cooperation aimed at solving problems facing indigenous peoples, coordinating development and human-rights efforts involving UN agencies and indigenous peoples, and serving as a focal point for discussions relating to indigenous peoples and states. ${ }^{19}$ The PFII is unique within the United Nations in that it is the only forum in which indigenous peoples sit as equals alongside governmentappointed members. ${ }^{20}$ An example of the PFII's role is its involvement in the health 
and well-being of indigenous peoples, coordinating efforts with the World Health Organization (WHO) and other UN agencies that are attempting to address health inequities in the Americas. ${ }^{21}$ The PFII has also focused attention on crucial issues such as the impacts of climate change on indigenous peoples and their habitats.

Another great achievement on the part of indigenous peoples in their ongoing pursuit of protection and recognition of their fundamental rights by the United Nations came in 2001 with the creation by the UNCHR of the mechanism of the UN Special Rapporteur on the situation of human rights and fundamental freedoms of indigenous peoples.

Later that year the chair of the UNCHR appointed Rodolfo Stavenhagen as Special Rapporteur for a three-year period; in 2004, the mandate of the Special Rapporteur was renewed for an additional period of three years. In 2007, after the adoption of the UN Declaration on the Rights of Indigenous Peoples, the new Human Rights Council (HRC) again renewed the Special Rapporteur's wide mandate and decided to add the task of "promoting the UN Declaration on the Rights of Indigenous Peoples and international instruments relevant to the advancement of the rights of indigenous peoples," thus establishing a clear legal framework for the different activities of the UN Special Rapporteur. James Anaya assumed the mandate from Rodolfo Stavenhagen on 1 May 2008.

Unlike the PFII and the new UN Expert Mechanism on the Rights of Indigenous Peoples, the Special Rapporteur is authorized to take complaints from indigenous individuals, groups, or communities, including requests for urgent action; to investigate them; to make visits to the countries where the complaints originate; and to make recommendations to the country violating indigenous human rights and to the various human-rights organs of the UN as to steps they should take to remedy the violations or to prevent future violations.

\section{Debates around the Declaration}

Debate surrounding the Declaration on the Rights of Indigenous Peoples ranged from disagreements over the use "indigenous people" versus "indigenous peoples" (the latter advocated by several states including Canada) to the issue of political selfdetermination, which a number of state governments saw as opening up the possibility of secession and, potentially, the dissolution of nation-states and the rise of intergroup conflict. Debate also focused on the issue of collective versus individual rights. Some states expressed concerns about the extent to which indigenous peoples would be granted control over land and subsurface resources such as minerals and petroleum.

A number of states, including Botswana, maintained that all peoples in the country are indigenous and that providing assistance to specific groups would be tantamount to promoting apartheid (separate development) like that practiced in South Africa until April 1994. ${ }^{22}$ Many indigenous peoples sought to ensure the right to culture, including the right to speak indigenous mother tongues in the face of opposition from governments. Indigenous peoples that are minorities in the states where they reside (or majorities, as in the cases of Guatemala and Bolivia) are all too often faced with state restrictions on cultural practices; in many instances there has been overt repression of peoples seeking to promote their own identities.

In many parts of the world "indigenousness" has taken on added political and economic significance because it is used to claim title over blocks of land and the resources on these lands, as well as development assistance or recognition from states and intergovernmental organizations. ${ }^{23}$ There are cases in which indigenous peoples, 
including small-scale isolated groups, have come into conflict with states over resources, sometimes with deadly results - as, for example, in the Amazon Basin of South America and in Southeast Asia. ${ }^{24}$

Today, indigenous peoples, like many other groups, are operating in a world in which conflicts are all too common. Some of these conflicts arise out of competition for resources, while others derive from interethnic tensions or from disagreements between the governments of states and peoples within those states. Indigenous peoples may also be victims of conflicts that do not concern them directly, as was the case, for example, with the Twa of Rwanda. A sizable proportion of the refugee population in some parts of the world (e.g., in Africa and Asia) is made up of indigenous and minority peoples. The concerns of indigenous peoples today, therefore, range from genocides and discriminatory treatment to the failure of states and transnational corporations to consult with indigenous peoples or to inform them about initiatives and plans that could affect their lands and livelihoods.

Some intergovernmental institutions, such as the World Bank, have attempted to take indigenous peoples into consideration and have established policies and guidelines aimed at promoting and protecting their rights. ${ }^{25}$ There are cases, however, in which the activities of intergovernmental organizations have had very negative consequences for indigenous peoples; in the case of the Chixoy Dam in Guatemala, for example, investigations have shown the World Bank's complicity in genocide. ${ }^{26}$

The formal adoption of the Declaration on the Rights of Indigenous Peoples by the UN General Assembly on 13 September 2007 was seen as an important victory by indigenous peoples around the world. The declaration acknowledges the occurrence of a wide range of violations against indigenous peoples and lays out minimum standards for ensuring dignity, well-being, and physical and cultural survival.

The Special Rapporteur on the situation of human rights and fundamental freedoms of indigenous people, Rodolfo Stavenhagen, in his statement on the occasion of the adoption of the declarationby the General Assembly, noted that the adoption of the declaration constituted a fundamental landmark for indigenous peoples and represented their important contribution to the construction of the international human-rights system. ${ }^{27}$

The process of achieving agreement on the declaration within the United Nations was not an easy one. Four states-the United States, Canada, Australia, and New Zealand-opposed the Declaration and voted against its adoption. Earlier in the process, the African Group of States had raised serious questions about the declaration's principles and implications. ${ }^{28}$ Concerns raised by various states included the perceived dangers of self-determination and self-government, which some states felt would threaten their territorial integrity and confer upon indigenous peoples the right of secession. There were also concerns that indigenous peoples would use some of the declaration's provisions on land, territories, and resources to control mineral and oil exploration and to limit economic development. Article 23 of the declaration states that "indigenous peoples have the right to determine and develop priorities and strategies for exercising their right to development," something that some states maintained was inappropriate because, in their view, governments ought to be the decision-making bodies with respect to national development.

An unqualified right to free, prior, and informed consent on all matters that affect indigenous peoples, some states believed, would give indigenous groups veto power over state policies and plans and over laws passed by legislative bodies. With respect to the issues of redress and restitution, states feared that the 
implementation of this provision would reopen agreements and settlements already established between indigenous peoples and states.

The concerns of the African Group of States related to a number of the forty-three articles of the Declaration on the Rights of Indigenous Peoples. It was argued, for instance, that the absence of a definition of indigenous peoples in the text would create legal problems for the implementation of the declaration. Article 3 on selfdetermination was opposed in part because of the possibility that ethnicity, culture, and language could easily become a rationale for groups seeking exclusivity within nation-states, whereas, in the opinion of these states, the United Nations has the responsibility to protect the integrity of nation-states. ${ }^{29}$ The African Group of States argued that the recognition, observance, and enforcement of treaties and agreements are the responsibility of the state.

Often, the term "indigenous" refers to individuals and groups who are descendants of the original populations (that is, the "first nations") of a country, but this is not, for example, how indigenous peoples in Africa see themselves. ${ }^{30}$

Admittedly, particular problems do arise in defining people as indigenous. An important criterion for "indigenousness" is the identification by people themselves of their distinct cultural identity. Most indigenous people prefer to reserve for themselves the right to determine who is and is not a member of their group. As Bernard Nietschmann puts it, "Like a nation, a people is self-defined."

In many areas, it is difficult to determine antecedence, since a variety of populations have moved into and out of local areas over time. Africa, the continent with the longest history of human occupation, contains the greatest range of human genetic and cultural diversity. As a result, there have been complex interactions between indigenous and non-indigenous groups in Africa, some of which have resulted in indigenous groups' being marginalized socially, politically, and economically. The establishment of majority rule in South Africa in 1994 and the passage of a new South African constitution, however, have provided hope for indigenous peoples throughout Africa.

The Constitution of Cameroon stipulates that "the State shall ensure the protection of minorities and preserve the rights of indigenous populations in accordance with the law." The term "indigenous" is not defined, yet Cameroon has created an Indigenous Peoples Development Plan, as well as a plan for indigenous and vulnerable peoples in its Poverty Reduction Strategy Paper. Indigenous peoples are also mentioned in legislation in Congo and Burundi. The African Commission on Human and Peoples' Rights underscores this kind of approach, noting that "a strict definition of indigenous peoples is neither necessary nor desirable."32

Indigenous peoples in Africa are highly diverse. They range from small communities of foragers (hunters and gatherers) such as the Twa in Central Africa to sedentary agropastoralists and peri-urban factory workers in the industrial economies of southern African states. ${ }^{33}$ The vast majority of African indigenous peoples have diversified economic systems, combining small-scale agriculture and livestock production with natural resource procurement and business activities.

Some indigenous groups in Africa do not live within individual countries but, rather, are found in several states, overlapping national borders. This is the case, for example, with the Ju/hoansi of northwestern Botswana and northeastern Namibia and the Maasai of Kenya and Tanzania. The transboundary nature of many indigenous peoples puts them in a special position vis-à-vis nation-states, many of 
which are concerned about their sovereignty and security and are attempting to prevent movements of people and goods across their borders.

The claims of indigenous peoples in Africa and other parts of the world are relatively similar: they wish to have their human rights respected; they want ownership and control over their own land and natural resources; and they want the right to participate through their own institutions in the political process at the nation-state, regional, and international levels. All these claims raise concerns on the part of states wishing to retain for themselves the right to determine the policies they pursue and the right to protect their populations and territories. Article 9 of the declaration, which states that "indigenous peoples and individuals have the right to belong to an indigenous community or nation, in accordance with the traditions and customs of the community or nations concerned," was opposed by the African Group of States because they felt that this clause could be interpreted to mean that tribal communities can choose to belong to one country while living in another. ${ }^{34}$

Because many of the indigenous groups of Africa remain unrecognized in the nation-states where they reside, they are seeking to organize themselves and to lobby in defense of their human rights. In doing so, they employ a variety of innovative strategies that range from the use of the Internet, geographic information system (GIS) tools, and global positioning system (GPS) instruments to conflict-resolution and negotiation techniques. Diplomacy and bargaining are also key strategies in indigenous peoples' interactions with other groups and state governments. Indigenous groups have also sought redress through the courts and have used the media to positive effect. ${ }^{35}$

Members of indigenous groups have taken part in international forums on indigenous peoples held by academic institutions and indigenous peoples' humanrights and advocacy organizations. ${ }^{36}$ While the indigenous movement is still in its infancy in Africa in many ways, steps are being taken toward establishing Africa-wide indigenous peoples' networks and promoting indigenous peoples' rights at the continental and regional levels, one example being the Indigenous Peoples of Africa Coordinating Committee (IPACC). Important work has been done by the African Commission's Working Group of Experts on Indigenous Populations/Communities; for example, their missions to various African countries have resulted in useful recommendations for improvements in policies and programs that relate to indigenous peoples.

In June 2006, the UN Human Rights Council adopted the Declaration on the Rights of Indigenous Peoples with a vote of thirty-two in favor and two against. Intense negotiations among states, indigenous groups, and support organizations in 2006-2007 eventually resulted in a compromise, and the declaration was passed by the General Assembly in September. Lobbying strategies, networking, and awareness campaigns were employed by indigenous peoples' delegations and by regional associations and NGOs, including the ACHPR, with strong support from the IWGIA, which engaged in lobbying and helped to win the votes of the African Group of States for a version of the declaration modified to meet the demands of various governments. ${ }^{37}$ Ultimately, there were 143 votes in favor of the declaration, four votes against, and eleven abstentions.

After the vote in favor of the Declaration on the Rights of Indigenous Peoples was announced, Victoria Tauli-Corpuz, chair of the PFII, and Les Malezer, chair of the Global Indigenous Peoples Caucus, were allowed to address the members of the 
General Assembly. They expressed their appreciation to the UN member states that voted in favor of the declaration. As Malezer noted,

The Declaration does not represent solely the viewpoint of the United Nations, nor does it represent solely the viewpoint of the Indigenous Peoples. It is a Declaration which combines our views and interests and which sets the framework for the future. It is a tool for peace and justice, based upon mutual recognition and mutual respect. ${ }^{38}$

The challenge now is to implement the provisions of the Declaration.

In her statement, Tauli-Corpuz stressed that "effective implementation of the Declaration would test the commitment of States and the whole international community to protect, respect, and fulfill indigenous peoples' collective and individual human rights"; she concluded her statement by calling on governments and civil society at large "to rise to the historic task before us and make the UN Declaration on the Rights of Indigenous Peoples a living document for the common future of humanity." 39

\section{Conclusions}

As Julian Burger notes, the Declaration on the Rights of Indigenous Peoples is a unique instrument in the UN system in that it was drafted with the participation of people who are both the victims of human-rights abuses and the potential future beneficiaries of its provisions. ${ }^{40}$ It is a unique document, as well, in that its drafting took into account a broad array of interests and was discussed extensively at the grassroots level as well as at the regional, national, and international levels. The UN Declaration on the Rights of Indigenous Peoples outlines the standards for what indigenous peoples feel are their fundamental human rights. It differs from other UN human-rights instruments in that it addresses the rights of indigenous peoples as collectivities instead of placing the emphasis on individual rights and freedoms. As Dalee Sambo Dorough said at the conference Being Indigenous in Today's World, held in Copenhagen on 6 October 2008, the adoption of the declaration "redefines the terms of our survival in international law." ${ }^{41}$ While it is a declaration and not a convention, and therefore is not binding on states, the Declaration on the Rights of Indigenous Peoples has the potential to become customary international law, and, as such, will henceforth have significant implications for the ways in which states behave toward indigenous peoples and for their deliberations and decision making vis-à-vis indigenous concerns.

The crucial issue now, we believe, is to find ways to compel states to comply with the international human-rights standards outlined in the declaration and to ensure the long-term survival and well-being of indigenous peoples throughout the world. Ways to do this include enhancing the capacities of states, indigenous peoples, and community-based organizations to plan and implement sustainable development and conservation strategies; engaging in human-rights education; promoting constitutional reform at the national level; forming networks; and undertaking collaborative activities at the international, national, or local level. Another way to ensure that indigenous peoples are protected from genocide is to take those responsible to court and prosecute them to the fullest extent of the law, as well as to impose sanctions on states that engage in genocide.

The new Human Rights Council's Expert Mechanism on Indigenous Peoples' Rights, the Special Rapporteur on the situation of human rights and fundamental freedoms of indigenous peoples, and the PFII, given their different mandates, should coordinate their efforts closely, paying particular attention to issues of genocide, 
ethnocide, and massive violations of human rights. Simply promoting democratic governance and participatory decision making is not enough; we must ensure that there is transparency, accountability, and fairness, and that international humanrights standards are applied universally, not only to member states of the United Nations but to all peoples, groups, and communities.

\section{Notes}

1. David Maybury-Lewis, "Genocide against Indigenous Peoples," in Annihilating Difference: The Anthropology of Genocide, ed. Alexander Laban Hinton, 43-53 (Berkeley: University of California Press, 2002); Patrick Brantlinger, Dark Vanishings: Discourse on the Extinction of Primitive Races 1800-1930 (Ithaca, NY: Cornell University Press, 2003); Robert K. Hitchcock and Tara M. Twedt, "Physical and Cultural Genocides of Indigenous Peoples," in Century of Genocide: Critical Essays and Eyewitness Accounts, ed. Samuel Totten and William S. Parsons, 413-58 (New York: Routledge, 2009).

2. Julian Burger, Report from the Frontier: The State of the World's Indigenous Peoples (London: Zed Press, 1987); Julian Burger, The Gaia Atlas of First Peoples: A Future for the Indigenous World (New York: Anchor Books, 1990); David Maybury-Lewis, Indigenous Peoples, Ethnic Groups, and the State (Boston: Allyn \& Bacon, 1997); John Bodley, Victims of Progress (Mountain View, CA: Mayfield Publishing, 1999); Patrick Thornberry, Indigenous Peoples and Human Rights (Manchester, UK: Manchester University Press, 2002); Robyn Eversole, John-Andrew McNeish, and Alberto D. Cimadamore, eds., Indigenous Peoples and Poverty: An International Perspective (London: Zed Books, 2005).

3. Eyassu Gayim and Kristian Myntti, eds., Indigenous and Tribal Peoples' Rights-1993 and After (Rovaneimi, Finland: Laplands University Press, 1997); Russel Lawrence Barsh, "Indigenous Peoples and the UN Commission on Human Rights: A Case of the Immovable Object and the Irresistible Force," Human Rights Quarterly 18 (1996): 782-813; Duncan Ivison, Paul Patton, and Will Sanders, eds., Political Theory and the Rights of Indigenous Peoples (Cambridge: Cambridge University Press, 2000); Ronald Niezen, The Origins of Indigenism: Human Rights and the Politics of Identity (Berkeley: University of California Press, 2003); Joshua Castellino and Naimn Walsh, eds., International Law and Indigenous Peoples (Leiden: Martinus Nijhoff, 2005); S. James Anaya, Indigenous Peoples in International Law, 3rd ed. (Oxford: Oxford University Press, 2008).

4. Niezen, The Origins of Indigenism, 70.

5. Minority Rights Group [MRG], State of the World's Minorities 2007 (London: MRG, 2007); Kathrin Wessendorf, ed., The Indigenous World 2008 (Copenhagen: International Work Group for Indigenous Affairs [IWGIA], 2008).

6. Al Gedicks, The New Resource Wars: Native and Environmental Struggles Against Multinational Corporations (Boston: South End Press, 1993); Al Gedicks, Resource Rebels: Native Challenges to Mining and Oil Corporations (Boston: South End Press, 2001).

7. Luis Rodriguez-Pinero, Indigenous Peoples, Postcolonialism, and International Law: The ILO Regime (1919-1989) (Oxford: Oxford University Press, 2005).

8. Russel L. Barsh and James Youngblood Henderson, The Road: Indian Tribes and Political Liberty (Berkeley: University of California Press, 1980); Stephen Cornell, The Return of the Native: American Indian Political Resurgence (New York: Oxford University Press, 1988); Ronald M. Berndt, ed., Aborigines and Change: Australia in the '70's (Canberra: Australian Institute of Aboriginal Studies, 1978); Stefano Varese, Witness to Sovereignty: Essays in the Indian Movement in Latin America (Copenhagen: IWGIA, 2006); Nancy Grey Postero and Leon Zamosc, eds. The Struggle for Indigenous Rights in Latin America (Brighton, UK: Sussex Academic Press, 2006).

9. See Wolfgang Mey, Genocide in the Chittagong Hill Tracts (Copenhagen: IWGIA, 1984); International Work Group for Indigenous Affairs [IWGIA], The Chittagong Hill Tracts (Copenhagen: IWGIA, 1991); and the various Chittagong Hill Tracts reports of the Chittagong Hill Tracts Commission, published by the IWGIA. 
10. Shelton Davis, Victims of the Miracle: Development and the Indians of Brazil (Cambridge: Cambridge University Press, 1977).

11. David Hyndman, Ancestral Forests and the Mountain of Gold: Indigenous Peoples and Mining in Indonesia (Boulder, CO: Westview Press, 1994).

12. Bodley, Victims of Progress; Jens Dahl, IWGIA: A History (Copenhagen: IWGIA, 2009).

13. Bradley Reed Howard, Indigenous Peoples and the State: The Struggle for Native Rights (DeKalb: Northern Illinois University Press, 2002).

14. Jose Martinez Cobo, Study of the Problem of Discrimination Against Indigenous Populations. Volume V: Conclusions, Proposals, and Recommendations (New York: United Nations, 1987).

15. Douglas Sanders, "The UN Working Group on Indigenous Populations," Human Rights Quarterly 11 (1989): 406-33.

16. See, e.g., Lee Swepston, "The Adoption of the Indigenous and Tribal Peoples Convention, 1989 (No. 169)," Law and Anthropology 5 (1990): 221-35. The text of the convention can be found in International Labour Organization [ILO], The Indigenous and Tribal Peoples Convention No. 169 of 1989 (Geneva: ILO, 1991).

17. Statements to this effect were made at the UN Conference on Discrimination Against Indigenous Populations in the Americas, held in Geneva in 1977; International Indian Treaty Council, "The Geneva Conference," Treaty Council News 1, 7 (1977): 1-35.

18. International Decade of the World's Indigenous People, UN General Assembly Resolution 48/163, UN Doc. A/RES/48/163 (21 December 1993), http://www.un-documents.net/ a48r163.htm (accessed 22 December 2008); see Office of the United Nations High Commissioner for Human Rights, "Indigenous Peoples" (2008), http://www2.ohchr.org/ english/issues/indigenous/(accessed 3 January 2009).

19. Lola García-Alix, The Permanent Forum on Indigenous Issues (Copenhagen: IWGIA, 2003).

20. Ibid., 6 .

21. Niezen, The Origins of Indigenism, 48-49; Raul A. Montenegro and Carolyn Stephens, "Indigenous Health in Latin America and the Caribbean," The Lancet 367 (2006): 1854-69.

22. See Robert K. Hitchcock “'We Are the First People': Land, Natural Resources, and Identity in the Central Kalahari, Botswana," Journal of Southern African Studies 28 (2002): 797-824.

23. Alesandra Xanthaki, Indigenous Rights and United Nations Standards: Self-Determination, Culture, and Land (Cambridge: Cambridge University Press, 2007); Laura Westra, Environmental Justice and the Rights of Indigenous Peoples: International and Domestic Legal Perspectives (London: Earthscan, 2008).

24. Beatriz Huertas Castillo, Indigenous Peoples in Isolation in the Peruvian Amazon: Their Struggle for Survival and Freedom (Copenhagen: IWGIA, 2004); Danilo Geiger, ed., Frontier Encounters: Indigenous Communities and Settlers in Asia and Latin America (Copenhagen: IWGIA, 2008).

25. World Bank, Indigenous Peoples, World Bank Operational Directive OP 4.10 (July 2005) (Washington, DC: World Bank, 2005).

26. Jaroslava Colajacomo, "The Chixoy Dam: The Aya Achi Genocide: The Story of Forced Resettlement," in Dams, Indigenous Peoples, and Ethnic Minorities, ed. Marcus Colchester, 64-79 (Copenhagen: IWGIA, 1999); Barbara Rose Johnston, Chixoy Dam Legacy Issues Study, vol. 1: Executive Summary Consequential Damages and Reparation: Recommendations for Remedy; vol. 2: Document Review and Chronology of Relevant Actions and Events; vol. 3: Consequential Damage Assessment of Chixoy River Basin Communities. (Santa Cruz, CA: Center for Political Ecology, 2005), http://www.centerforpoliticalecology.org/chixoy.html (accessed 22 December 2008).

27. "Adoption of Declaration on Rights of Indigenous People a Historic Moment for Human Rights, United Nations Expert Says" (statement by Rodolfo Stavenhagen, Geneva, Switzerland, 14 September 2007), http://www2.ochr.org/english/issues/indigenous/ declaration.htm (accessed 3 January 2009). 
28. African Group of States, Draft Aide Memoire: United Nations Declaration on the Rights of Indigenous People 9 November 2006 (New York: United Nations, 2006).

29. Ibid., 2.

30. Independent Commission on International Humanitarian Issues, Indigenous Peoples: A Global Quest for Justice (London: Zed Press, 1987), 6.

31. Bernard Neitschmann, "The Fourth World: Nations versus States," in Reordering the World: Geopolitical Perspectives on the 21st Century, ed. George J. Demko and William B. Woods, 225-42 (Boulder, CO: Westview Press, 1994), 227.

32. African Commission on Human and Peoples' Rights [ACHPR], Report of the African Commission's Working Group of Experts on Indigenous Populations / Communities. (Banjul, The Gambia: ACHPR, African Union; Copenhagen: IWGIA, 2005), 86-88.

33. See Richard B. Lee and Richard Daly, eds., The Cambridge Encyclopedia of Hunters and Gatherers (Cambridge: Cambridge University Press, 1999), 175-229.

34. African Group of States, Draft Aide Memoire, 3.

35. This is the case, for example, for the Khomani San of South Africa, who were able to obtain co-management rights over the Kalahari Transfrontier Park and who received compensation for lands and assets lost in the past in an out-of-court settlement in the late 1990s.

36. For example, a conference on indigenous peoples of eastern, central, and southern Africa was held in Arusha, Tanzania, from 18 to 22 January 1999; it was organized by the International Work Group for Indigenous Affairs and the Pastoralist Indigenous Non-government Organizations (PINGOs) Forum.

37. Wessendorf, The Indigenous World 2008, 526-34.

38. Les Malezer, "Statement by the Chairman, Global Indigenous Caucus" (13 September 2007), http://www.arena.org.nz/unindig6.htm (accessed 15 January 2009).

39. "Statement of Victoria Tauli-Corpuz, Chair of the United Nations Permanent Forum on Indigenous Issues, on the Occasion of the Adoption of the United Nations Declaration on the Rights of Indigenous Peoples," 61st Session of the General Assembly, New York, NY (13 September 2002), http://www.un.org/esa/socdev/unpfii/documents/ Declaration_ip_vtc.doc (accessed 15 January 2009).

40. Julian Burger, "Indigenous Peoples and the United Nations," in The Human Rights of Indigenous Peoples, ed. Cynthia Price Cohen, 3-16 (Ardsley, NY: Transnational Publishers, 1998), 6.

41. Minutes of the conference Being Indigenous in Today's World (Copenhagen, 6 October 2008). The conference was sponsored by the IWGIA. 